\title{
Lack of Pathology in a Triple Transgenic Mouse Model of Alzheimer's Disease after Overexpression of the Anti- Apoptotic Protein Bcl-2
}

\author{
Troy T. Rohn, ${ }^{1}$ Veera Vyas, ${ }^{1}$ Tatiana Hernandez-Estrada, ${ }^{2}$ Kathryn E. Nichol, ${ }^{2}$ Lori-Ann Christie, ${ }^{2}$ and Elizabeth Head ${ }^{2}$ \\ ${ }^{1}$ Department of Biology, Boise State University, Boise, Idaho 83725, and ${ }^{2}$ Institute for Brain Aging and Dementia, Department of Neurology, University of \\ California, Irvine, Irvine, California 92697
}

\begin{abstract}
Alzheimer's disease $(\mathrm{AD})$ is characterized by the accumulation of plaques containing $\beta$-amyloid $(\mathrm{A} \beta$ ) and neurofibrillary tangles (NFTs) consisting of modified tau. Although $\mathrm{A} \beta$ deposition is thought to precede the formation of NFTs in AD, the molecular steps connecting these two pathologies is not known. Previous studies have suggested that caspase activation plays an important role in promoting the pathology associated with AD. To further understand the contribution of caspases in disease progression, a triple transgenic Alzheimer's mouse model overexpressing the anti-apoptotic protein $\mathrm{Bcl}-2$ was generated. Here we show that overexpression of Bcl-2 limited caspase-9 activation and reduced the caspase cleavage of tau. Moreover, overexpression of Bcl-2 attenuated the processing of APP (amyloid precursor protein) and tau and reduced the number of NFTs and extracellular deposits of $A \beta$ associated with these animals. In addition, overexpression of $\mathrm{Bcl}-2$ in 3xTg-AD mice improved place recognition memory. These findings suggest that the activation of apoptotic pathways may be an early event in $\mathrm{AD}$ and contributes to the pathological processes that promote the disease mechanisms underlying $\mathrm{AD}$.
\end{abstract}

Key words: amyloid precursor protein; $\beta$-amyloid; caspase; mouse model; neurofibrillary tangles; plaques; tau; Bcl-2

\section{Introduction}

Apoptosis is a gene-directed suicidal mechanism that regulates and controls cell death during development and maturation in a variety of cell types (Vaux and Korsmeyer, 1999). In the CNS, between 20 and $80 \%$ of neurons undergo apoptosis before adulthood, providing a pivotal role in molding the nervous system's final organization and function (Oppenheim, 1991). Although critical for the final sculpting of the CNS during development, the aberrant activation of apoptotic pathways has also been reported in numerous neurodegenerative diseases, including Alzheimer's disease (AD) (LeBlanc, 2005). AD is characterized neuropathologically by the accumulation of senile plaques composed primarily of $\beta$-amyloid (A $\beta$ ) and neurofibrillary tangles (NFTs) containing abnormally phosphorylated tau (Golde et al., 2006). Several studies suggest that $A \beta$ aggregates trigger subsequent NFT formation and neurodegeneration (Hardy and Selkoe, 2002; Golde et al., 2006). Although there is strong experimental support for the amyloid cascade hypothesis (Hardy and Selkoe, 2002; Golde et al., 2006), the steps interconnecting A $\beta$ with NFTs are

Received Sept. 14, 2007; revised Jan. 28, 2008; accepted Jan. 30, 2008.

This work was funded by National Institutes of Health (NIH)/National Center for Research Resources Grant P20RR016454, a grant from the American Health Assistance Foundation (T.T.R.), and by NIH/National Institute on Aging, University of California, Irvine Alzheimers Disease Research Center Grant P50 AG16573. We thank Dr. Sheng T. Hou (Experimental NeuroTherapeutics Laboratory, National Research Council Institute for Biological Sciences, National Research Council Canada, Ottawa, Ontario, Canada) for providing us with tissue sections from MCA0 mice. This article is freely available online through the J Neurosci Open Choice option.

Correspondence should be addressed to Troy T. Rohn, Department of Biology, Science/Nursing Building, Room 228, Boise State University, Boise, ID 83725. E-mail: trohn@boisestate.edu.

DOI:10.1523/JNEUROSCI.5620-07.2008

Copyright (C) 2008 Society for Neuroscience $\quad 0270-6474 / 08 / 283051-09 \$ 15.00 / 0$ largely unknown. One possible link between $\mathrm{A} \beta$ and NFTs is the activation of caspases, proteolytic enzymes responsible for the proper execution of programmed cell death or apoptosis (Riedl and Shi, 2004). Several studies have implicated the activation of caspases and cleavage of amyloid precursor protein (APP) and tau, which in turn may facilitate the production of $A \beta$ as well as promote NFT formation in AD (Gervais et al., 1999; Gamblin et al., 2003; Rissman et al., 2004). These studies demonstrated the presence of caspase cleavage products (CCPs) of tau, along with associated markers of NFTs in the human AD brain, and supported the notion that NFT and A $\beta$ may be interconnected through a common caspase-mediated pathway.

To further understand the contribution of caspases in disease progression, a transgenic Alzheimer's mouse model overexpressing the anti-apoptotic protein $\mathrm{Bcl}-2$ was generated. Here, we show that overexpression of $\mathrm{Bcl}-2$ limited the degree of caspase activation, prevented the formation of plaques and tangles, and improved memory retention in $\mathrm{AD}$ mice. These findings suggest that if one could selectively increase the levels or activity of Bcl-2 in neurons of $\mathrm{AD}$ patients, this could provide an effective means of treating this disease.

\section{Materials and Methods}

Animals. The generation and characterization of 3xTg-AD mice have been described previously (Oddo et al., 2003). To generate 3xTg-AD mice that overexpress the anti-apoptotic protein $\mathrm{Bcl}-2$, 3xTg-AD mice harboring three known mutations, human $\mathrm{APP}_{\mathrm{Swe}_{\mathrm{e}}}$, human $\operatorname{tau}_{\mathrm{P} 301 \mathrm{~L}}$, and $\mathrm{PS}_{\mathrm{M} 146 \mathrm{~V}}$, were crossed with Tg mice that overexpress the human Bcl-2 gene in all postmitotic neurons (Martinou et al., 1994). Founder mice that were Bcl-2 positive by PCR were further backcrossed to $3 \times \mathrm{Tg}-\mathrm{AD}$ to 
generate F2 founder mice. Littermates that were negative for the human $\mathrm{Bcl}-2$ gene were used for comparison. Both 3xTg-AD mice and Bcl-2overexpressing (OE) mice were bred and maintained on a C57BL/6 background.

Genotyping of transgenic mice. Mice were genotyped by reverse transcription-PCR amplification of tail DNA using published primer sequences. For Bcl-2, the following primers were used: BTM1', 5'-ATGAGCCTTGGGACTGTGAA-3'; BTM2，5'-GAAGACTCTGCTCAGTTTGG-3'. A $400 \mathrm{bp}$ band indicated a positive signal for the presence of the $\mathrm{Bcl}-2$ transgene. In addition, PCR amplification was performed using published primer sequences for human tau and APP for 3xTg-AD mice (LaFerla et al., 1995; Sugarman et al., 2002). For the PS1 ${ }_{\mathrm{M} 146 \mathrm{~V}}$ gene, the following primers were used: 5'-CACACGCAACTCTGACATGCACAGGC-3' and 5' -AGGCAGGAAGATCACGTGTTCAAGTAC-3'.

Antibody dilutions. Primary antibodies were diluted as follows: AT-100 (1:100; Pierce, Rockford, IL), AT8 (1:500, Pierce), PHF-1 (1:500), A $\beta_{1-42}$ (1:200; Biosource, Camarillo, CA), human Bcl-2, clone Bcl-2-100 (1:200; Sigma, St. Louis, MO), anti-APP, clone 22C11 (1:1000; Millipore, Billerica, MA), polyclonal antibody to active caspase-3 (CM1; 1:500; BD Biosciences PharMingen, San Jose, CA), $\beta$-actin rabbit polyclonal antibody (ab8227; 1:400; Abcam, Cambridge, MA), and anti-caspase-9, proform and large active subunit, AB16969 [1:100 for immunohistochemistry $(\mathrm{IH})$ and 1:250 for Western blotting (WB)] (Millipore). Two different caspase cleavage site-directed antibodies to caspase-cleaved tau were used: TauCCP (1:100; in-house rabbit polyclonal antibody) and TauC3 (1:100 for IH and 1:500 for WB) (Millipore).

Tissue acquisition. Mice were anesthetized with pentobarbital and perfused with saline, and the brains were rapidly removed. Brains were divided into hemispheres, and one hemisphere was sunk in $4 \%$ phosphate-buffered paraformaldehyde, while the other hemisphere was snap frozen at $-50^{\circ} \mathrm{C}$ in isopentane. Mouse brains were mounted coronally, sectioned serially at $50 \mu \mathrm{m}$ on a vibratome, and stored for immunohistochemistry. Frozen brain tissue was used for immunoblot and ELISA analysis.

Immunohistochemistry and immunofluorescence. Free-floating 50- $\mu \mathrm{m}$ thick serial sections were used for immunohistochemical and immunofluorescence studies as previously described (Mouser et al., 2006). Antigen visualization was determined using $\mathrm{ABC}$ complex ( $\mathrm{ABC}$ Elite immunoperoxidase kit; Vector Laboratories, Burlingame, CA), followed by DAB substrate (Vector Laboratories). For immunofluorescence studies, antigen visualization was accomplished using an Alexa Fluor 488labeled tyramide [green; excitation wavelength/emission wavelength $(\mathrm{Ex} / \mathrm{Em})=495 / 519]$ or streptavidin Alexa Fluor 555 (red; Ex/Em = 555/565), both from Invitrogen (Carlsbad, CA).

Western blot analysis. Sample preparation was according to Oddo et al. (2003). Western blot analysis was performed using the One-Step Advanced Western mouse kit according to the manufacturer's instructions (GenScript, Piscataway, NJ). All samples were analyzed for protein content using the BCA assay (Pierce) to ensure equal protein loading. In addition, Western blot analysis was performed using a $\beta$-actin antibody (1:400) as a loading control.

ELISA of $A \beta_{1-40}$ and $A \beta_{1-42}$. $\mathrm{A} \beta$ was sequentially extracted from $\sim 17-$ $122 \mathrm{mg}$ of frozen cortex and hippocampus in $0.1 \mathrm{M}$ Tris, $\mathrm{pH} 6.8$, with $1 \%$ SDS and a protease inhibitor mixture (Roche, Indianapolis, IN) at $1 \mathrm{ml}$ of buffer $/ 150 \mathrm{mg}$ of wet weight tissue, sonicated, and centrifuged at $4^{\circ} \mathrm{C}$ at $100,000 \times g$ for $1 \mathrm{~h}$. The pellet was resuspended in $70 \%$ formic acid and sonicated on ice. After centrifugation at $4^{\circ} \mathrm{C}$ at $100,000 \times g$ for $1 \mathrm{~h}$, the supernatant was collected and assayed. Brain samples were run in triplicate on ELISA plates coated with a monoclonal anti-A $\beta 1-16$ antibody (provided by Dr. William Van Nostrand, Stony Brook University, Stony Brook, NY), and detection was by an in-house biotinylated anti-A $\beta_{1-40}$ and anti-A $\beta_{1-42}$ at 1:1000 followed by streptavidin HRP 1:4000. For standards, $\mathrm{A} \beta_{1-40}$ and $\mathrm{A} \beta_{1-42}$ Ultra Pure, HFIP (Millipore catalog \#AG962 and \#AG698, respectively) were used.

Behavior assessment. Assessment of cognition of three 24-month-old $3 \mathrm{xTg}-\mathrm{AD} / \mathrm{Bcl}-2-\mathrm{OE}$ and three $3 \mathrm{xTg}-\mathrm{AD} / \mathrm{Bcl}-2$-negative mice was according to the procedure of Mumby et al. (2002). This procedure is a variation of the novelty-preference paradigm involving familiarizing mice with two different objects, each in a unique context, and exploratory prefer- ence is measured in which both objects are presented in one of the two contexts. Cognitively impaired animals will spend less time exploring the object that was in a context different from that during familiarization (Mumby et al., 2002). Individual mice (blind to experimenter) were tested on three separate occasions, and the mean ratio was analyzed for statistical differences using one-tailed Student's $t$ test. In one case, we compared directly the performance of a single $3 \mathrm{xTg}-\mathrm{AD} / \mathrm{Bcl}-2$-negative mouse versus a $3 \mathrm{xTg}-\mathrm{AD} / \mathrm{Bcl}-2$-positive mouse. These data were analyzed using a single-sample $t$ test against chance values and the significance is versus chance, not compared with each animal. We also pooled data from $n=3$ from each group (3xTg-AD/Bcl-2 positive or 3xTg-Ad/ $\mathrm{Bcl}-2$ negative), and in this case $p$ values represent significant differences in performance between these two groups of animals.

Cerebral ischemia produced by middle cerebral artery occlusion. Brain sections were generously provided to us by Dr. Sheng T. Hou (Experimental NeuroTherapeutics Laboratory, National Research Council Institute for Biological Sciences, National Research Council Canada, Ottawa, Ontario, Canada). C57BL/6 mice (20-23 g) were subjected to middle cerebral artery occlusion (MCAO) as described previously (Hou et al., 2006). Briefly, under anesthesia, mice were subjected to MCAO using an intraluminal filament for $1 \mathrm{~h}$. After $1 \mathrm{~h}$ of MCAO, the filament was removed and blood flow was restored for $24 \mathrm{~h}$, at which time animals were killed. Mouse brains were perfused with $10 \%$ formalin in PBS, then postfixed in $10 \%$ formalin for $4 \mathrm{~h}$ and cryoprotected overnight in phosphate buffer containing $30 \%$ sucrose at $4^{\circ} \mathrm{C}$. After fixation, brains were sectioned into $50 \mu \mathrm{m}$ free-floating sections to be processed by immunohistochemistry. Ischemic infarct areas were identified by Hoechst staining as described previously (Hou et al., 2006).

FluoroJade Clabeling. To assess for neurodegeneration, the fluorescent dye, FluoroJade C (Millipore, catalog \#AG325) was used on 24-monthold 3xTg-AD animals and, as a positive control, MCAO mice. Staining was as previously described by Bian et al. (2007). Briefly, fixed brain sections were mounted and pretreated for $5 \mathrm{~min}$ in an $80 \%$ alcohol solution containing $1 \%$ sodium hydroxide, followed by a $70 \%$ alcohol and a distilled water wash for $2 \mathrm{~min}$. Sections were then incubated for 10 $\min$ in a $0.06 \%$ potassium permanganate solution followed by rinsing in distilled water for $2 \mathrm{~min}$. Sections were then transferred into a $0.0001 \%$ solution of FluoroJade C containing $0.1 \%$ acetic acid for $10 \mathrm{~min}$. After three successive washes in distilled water for $1 \mathrm{~min}$, slides were dried, dehydrated, and coverslipped with Depex.

\section{Results}

\section{Reduction in caspase activation and the caspase cleavage of tau in 3xTg-AD/Bcl-2-OE mice}

To test the hypothesis that the activation of caspases plays an important and early role underlying the disease mechanisms in $\mathrm{AD}$, we developed a novel transgenic mouse model of $\mathrm{AD}$ that overexpressed the human anti-apoptotic protein $\mathrm{Bcl}-2$ in postmitotic neurons. To accomplish this, we used transgenic mice that harbor three known AD mutations: $\mathrm{PS}_{\mathrm{M} 146 \mathrm{~V}}, \mathrm{APP}_{\mathrm{Swe}}$, and $\operatorname{tau}_{\mathrm{P} 301 \mathrm{~L}}$. These mice, termed 3xTg-AD mice, progressively develop plaques and tangles in a manner that closely recapitulates the disease process in the human AD brain (Oddo et al., 2003). $3 \times \mathrm{Tg}-\mathrm{AD}$ mice were crossed with transgenic mice that specifically overexpress human Bcl-2 in neurons of the CNS (Martinou et al., 1994). Bcl-2 is an anti-apoptotic protein primarily expressed in mitochondria and the outer nuclear membrane, which prevents caspase- 9 activation through an interaction with Apaf-1 (LeBlanc, 2003). The rationale for using Bcl-2 is that Bcl-2 represents a critical convergence point that prevents the activation of the intrinsic receptor pathway of apoptosis implicated in $\mathrm{AD}$ ( $\mathrm{Su}$ et al., 1996; Letai, 2005; Bredesen et al., 2006). Moreover, overexpression of Bcl-2 has been shown to prevent neuronal apoptosis (Martinou et al., 1994) and delay symptom onset in a transgenic mouse model of amyotrophic lateral sclerosis (Kostic et al., 1997).

3xTg-AD mice were crossed with Bcl-2-OE mice, and progeny 
A.

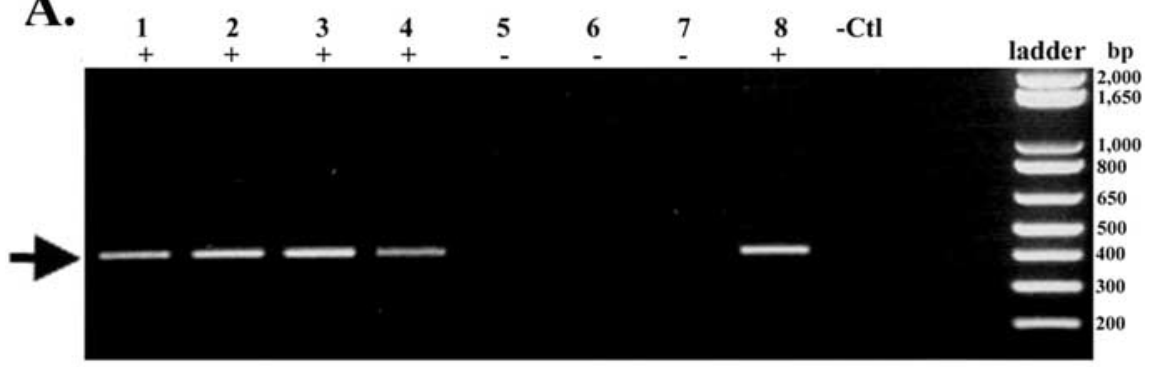

B.
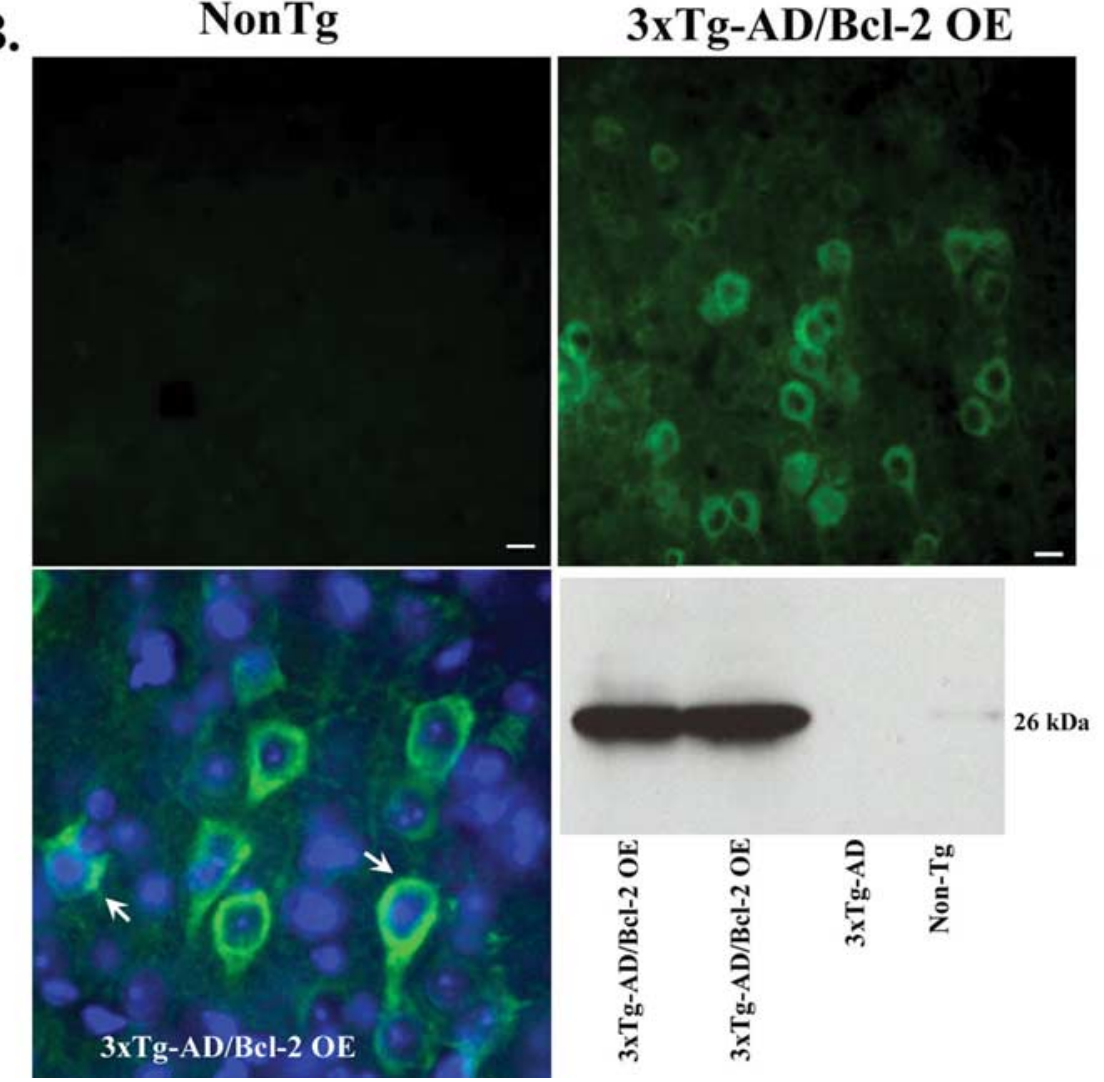

Figure 1. Characterization of $3 x T g-A D / B C l-2-0 E$ mice. $A, 3 x T g-A D$ mice were bred to $B C l-2-0 E$ mice to generate $F 1$ founder mice. $3 x \mathrm{Tg}-\mathrm{AD} / \mathrm{BCl}-2-0 \mathrm{E}$ mice from this cross were than backcrossed with $3 \times \mathrm{Tg}-\mathrm{AD}$ mice for the purpose of generating $\mathrm{F} 2$ founder mice. The presence of the $\mathrm{BCl}-2$ transgene of $\mathrm{F} 2$ mice was confirmed by $\mathrm{PCR}$ using primer sequences for the human $\mathrm{BCl}-2$ gene (arrow). As depicted, mice 1-4 and 8 were identified as being positive for the human $\mathrm{BCl}-2$ transgene. $\boldsymbol{B}$, Representative immunofluorescence labeling in an 18-month-old 3xTg-AD/BCl-2-0E mouse showing the cytoplasmic expression of $\mathrm{BCl}-2$ in the cortex. Bottom left, $\mathrm{Bcl}-2$ staining (green) with nuclear staining using Hoechst (blue). Bottom right, Western blot analysis confirming the presence of the human $\mathrm{BCl}-2$ protein.

were aged to $6,12,18$, or 24 months of age and analyzed. Figure 1 depicts the characterization of 3xTg-AD/Bcl-2-OE mice. As Figure $1 A$ shows, $3 x T g-A D / B c l-2-O E$ mice were identified by PCR, immunofluorescence confirmed the cytoplasmic expression of Bcl-2 (Fig. $1 \mathrm{~B}$ ), and Western blot analysis revealed a single band corresponding to the correct molecular weight for native human $\mathrm{Bcl}-2$ protein (Fig. $1 \mathrm{~B}$ ). The overexpression of $\mathrm{Bcl}-2$ was confirmed in all age groups examined, and there were no changes in expression with age.

In a first set of experiments, we examined mice for caspase activation using antibodies for both caspase- 9 and caspase-3. We found a striking pattern of distribution for caspase- 9 in the neocortex: in 3xTg-AD/Bcl-2-OE mice, the expression of caspase-9 appeared primarily nuclear (Fig. 2C, arrows). This finding supports previous studies demonstrating the nuclear localization for procaspase-9 (Ritter et al., 2000; Shimohama et al., 2001). A similar pattern of expression was observed for age-matched nontransgenic (NonTg) control mice, although the nuclear labeling was more diffuse and there was evidence for cytoplasmic staining in some neurons (Fig. $2 A$ ). In contrast, for $3 \mathrm{xTg}-\mathrm{AD}$ (Fig. $2 B$ ), prominent cytosolic staining was observed for caspase-9. These results were confirmed in hippocampal sections after doublelabeling immunofluorescence experiments using a nuclear label, propidium iodide (Fig. 2D-F). Western blot analysis indicated the presence of the large active domain for caspase-9 in 3xTg-AD/Bcl-2negative mice, which was largely absent in NonTg controls or in 3xTg-AD/Bcl-2-OE mice (data not shown). Collectively, these results suggest that the activation of caspase- 9 and its subcellular redistribution is prevented in $3 \times \mathrm{Tg}-\mathrm{AD}$ mice after overexpression of $\mathrm{Bcl}-2$. In addition, the activation of caspase- 3 , a critical target for caspase-9 cleavage and a known executioner caspase, was evident in the neocortex and hippocampus of 3xTg-AD mice after application of an antibody to the active domain of caspase-3 (Fig. 2G-L). In contrast, a general lack of staining was observed in $3 x T g-A D / B c l-2-O E$ mice (Fig. $2 I, L)$.

To determine whether the overexpression of Bcl-2 prevents the caspase cleavage of tau, 6-month-old animals were examined using an antibody specific for the C-terminal caspase cleavage of tau at aspartic acid 421 (Rissman et al., 2004). Application of this polyclonal antibody (TauCCP) revealed no specific labeling in NonTg animals (Fig. 3A), but labeling in the cytoplasm of a subset of neurons and apical dendrites in the CA1 region of the hippocampus of 6-month-old 3xTg-AD mice (Fig. $3 B$ ), which was largely limited to portions of the apical dendrites in 6-month-old 3xTg-AD mice overexpressing Bcl-2 (Fig. 3C). These same mice were screened for the presence of tangle markers (AT8 and PHF-1), both of which were negative, in line with previous studies indicating that $3 \mathrm{xTg}-\mathrm{AD}$ mice do not exhibit significant tangle formation until 15-18 months of age (Oddo et al., 2003). Data illustrating TauCCP immunoreactivity as early as 6 months in $3 \mathrm{xTg}-\mathrm{AD}$ mice are consistent with early caspase cleavage of tau preceding overt tangle formation in the human AD brain (Rissman et al., 2004).

To determine whether caspase cleavage of tau was either prevented or delayed in 3xTg-AD/Bcl-2-OE mice, experiments were extended to include 12- (Fig. 3E-H) and 18-month-old animals (Fig. 3I-L). In both age groups, caspase cleavage of tau was significantly reduced or limited to apical dendrites after overexpression of Bcl-2 (Fig. $3 E-L$ ). To confirm the presence of caspasecleaved tau in this cohort, experiments were undertaken using a 
similar site-directed antibody to tau (TauC3) developed by Gamblin et al. (2003). Application of TauC3 revealed labeling of neurons in 12- and 18-monthold 3xTg-AD mice within the CA1 region of the hippocampus in a similar manner as our TauCCP antibody (data not shown).

The presence of caspase-cleaved tau and its prevention after overexpression of Bcl-2 was confirmed by Western blot analysis of total brain extracts from 12-monthold animals using the TauC3 antibody (Fig. 3D). Immunohistochemical quantification indicated an age-dependent increase in the number of TauCPP-positive neurons in the CA1 region of the hippocampus (Fig. 3M). It is noteworthy that the presence of TauCCP-positive neurons was also evident in the amygdala of 18month-old 3xTg-AD animals (data not shown).

\section{Accumulation of human pathological tau and absence of tangle formation in 3xTg-AD/Bcl-2-OE mice}

Because caspase cleavage of tau was largely prevented in mice overexpressing Bcl-2, we hypothesized that caspase-like activity may play an important role in the turnover and processing of tau. To examine this possibility, we used an antibody against human pathological tau (HT7). HT7 recognizes amino acids $159-163$ of normal and PHF tau in human and bovine but does not cross-react with rat or mouse tau (Mercken et al., 1992). Using HT7, we found that the extent of total pathological human tau was significantly higher in 3xTg-AD mice overexpressing Bcl-2 (Fig. $4 B)$ compared with $3 x \mathrm{Tg}-\mathrm{AD}$ mice alone (Fig. 4A). Western blot analysis using HT7 indicated a significant increase in total human tau protein in $3 x T g-A D / B c l-2-O E$ mice compared with littermates that were Bcl-2 negative (Fig. 4C). Quantification of Western blots confirmed an $\sim 2.5$-fold increase in the accumulation of total tau in $3 x T g-A D / B c l-2-O E$ mice compared with 3xTg-AD/Bcl-2negative mice alone (Fig. $4 \mathrm{D}$ ). In addition, despite the accumulation of human pathological tau in 3xTg-AD/Bcl-2-OE mice, an apparent lack of NFT pathology by AT8 (Fig. $4 E-H$ ) or by PHF-1 (Fig. $4 I-L$ ) was observed compared with $3 \times$ Tg-AD mice, suggesting that the caspase cleavage of tau is a prerequisite for NFT formation.

\section{Accumulation of human APP and lack of extracellular deposits of $\mathrm{A} \boldsymbol{\beta}$ in 3xTg-AD/Bcl-2-OE mice}

Because of the prominent role for caspase-like activity on tau turnover, we investigated whether a similar effect occurred with the APP. APP is a substrate for caspase-3-mediated cleavage, which may contribute to $\mathrm{A} \beta$ formation, synaptic loss, and the behavioral changes associated with AD (Gervais et al., 1999; Lu et al., 2000; Zhao et al., 2003; Galvan et al., 2006). Because of a putative role for caspase cleavage in the processing of APP, we hypothesized that overexpression of human Bcl-2 in 3xTg-AD
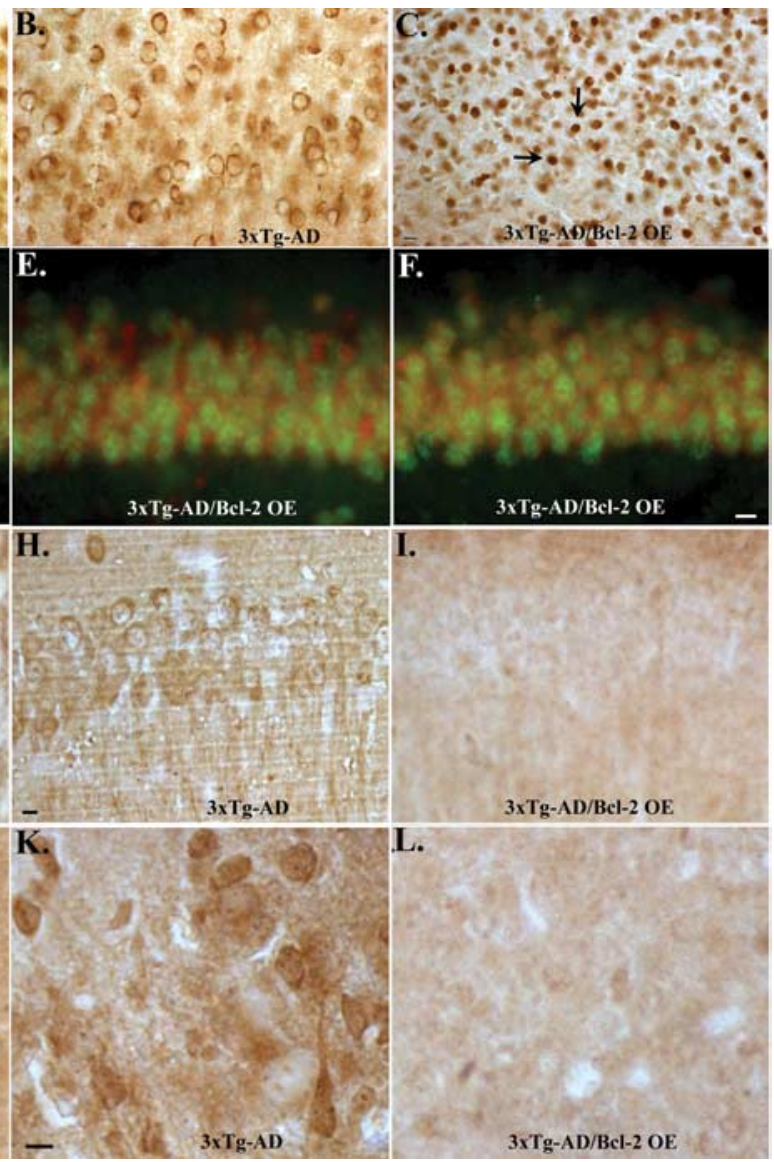

Figure 2. Reduced caspase- 9 and caspase-3 activation in 3xTg-AD mice after overexpression of $B C l-2$. $A-C$, Representative staining in the cortex of a NonTg mouse ( $\boldsymbol{A})$, 12-month-old 3xTg-AD mouse (B), and 12-month-old 3xTg-AD/BCl-2-0E mouse (C) application of a polyclonal antibody to caspase-9 (1:100). Although the majority of labeling was cytoplasmic for 3xTg-AD , which was largely absent in 3xTg-AD mice overexpressing $\mathrm{BCl}-2(\boldsymbol{I}, \mathbf{L})$. Representative staining is shown from a total of $n=4$ animals for each cohort. Scale bars, $10 \mu \mathrm{m}$.

mice may lead to a decrease in the processing of APP as well as extracellular deposition of $\mathrm{A} \beta$. As an initial approach, cortical sections were processed using anti-A $\beta$ monoclonal antibody (mAb) 1560 (clone 6E10). This antibody is known to react with both the A $\beta$ peptide and with full-length APP (Oddo et al., 2006). Surprisingly, in 12-month-old animals, intense intracellular cytoplasmic and dendritic labeling was observed in $3 \mathrm{xTg}-\mathrm{AD} / \mathrm{Bcl}-$ 2-OE compared with $3 x T g-A D$ mice (Fig. $5 A-C$ ). A similar finding was observed in 18-month-old animals, and in this case extracellular deposits were evident in 3xTg-AD mice (Fig. 5D-F). To determine whether the increase in intraneuronal staining was caused by $\mathrm{A} \beta$ or APP, cortical sections were next stained with $22 \mathrm{C} 11$, which is specific for the full-length APP protein. As with $\mathrm{mAb} 1560$, there was an increase in intraneuronal labeling with $22 \mathrm{C} 11$ in two different $3 \times \mathrm{Tg}-\mathrm{AD} / \mathrm{Bcl}-2-\mathrm{OE}$ mice compared with $3 \times$ Tg-AD mice (Fig. $5 G-I$ ). These data suggest that the increase in staining observed with mAb 1560 is largely a result of an increased intracellular accumulation of APP and not A $\beta$. We confirmed the higher protein levels of APP in $3 \mathrm{xTg}-\mathrm{AD} / \mathrm{Bcl}-$ 2-OE mice by Western blot analysis using 22C11 (Fig. 5J).

If overexpression of $\mathrm{Bcl}-2$ leads to a decrease in APP processing, then we hypothesized that there would be a decrease in the 


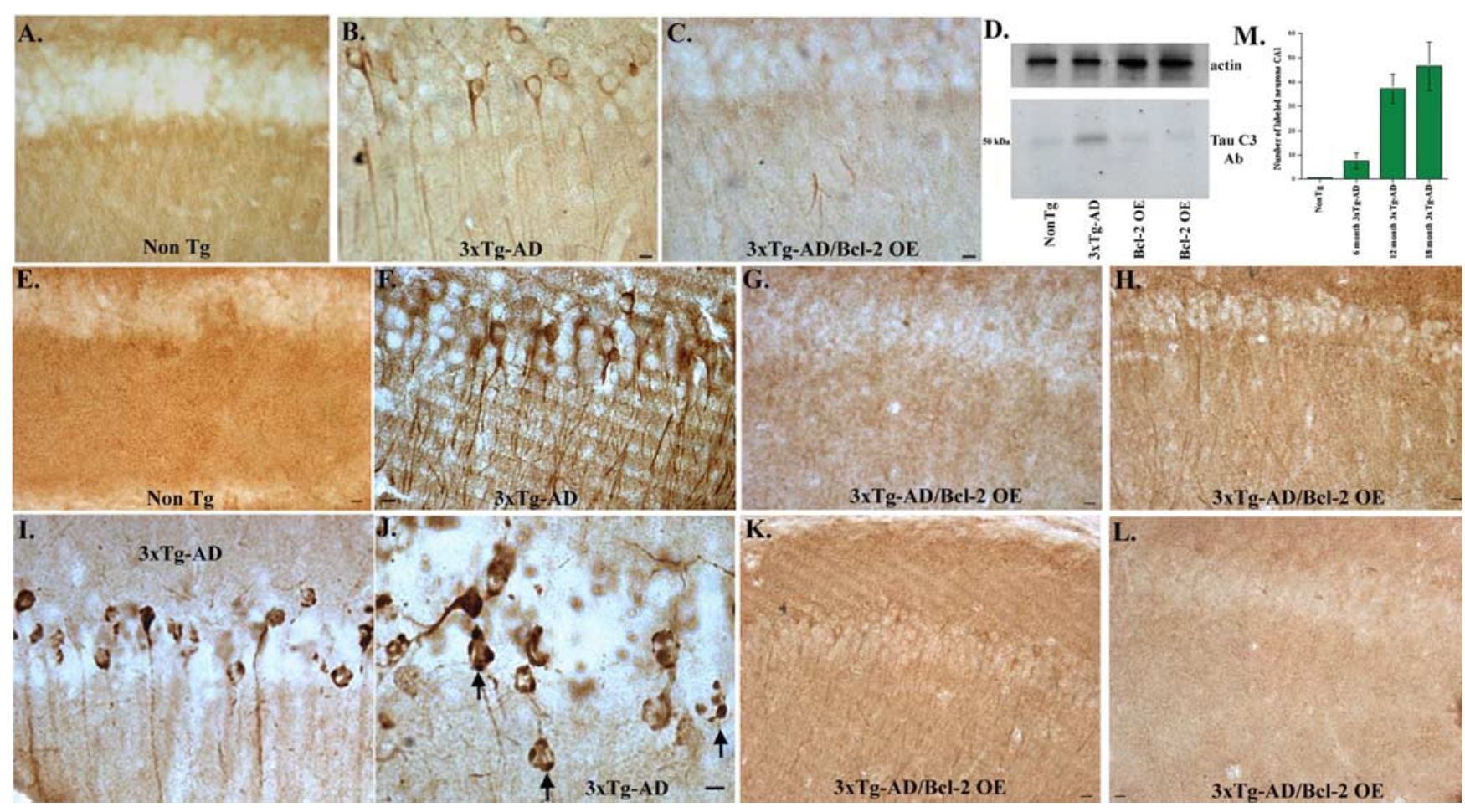

Figure 3. Reduced caspase cleavage of tau in 3xTg-AD mice after overexpression of BCl-2.A-C, CA1 labeling in the hippocampus was evident in 6-month-old 3xTg-AD mice after application of an antibody specific for caspase-cleaved tau, TauCCP (Rissman et al., 2004) (B). No labeling was evident in age-matched NonTg mice $(\boldsymbol{A})$, and it was limited to parts of the apical dendrites in $3 \times \mathrm{XT}$-AD mice overexpressing BCl-2 (C).E-H, Immunohistochemical labeling with TauCCP in the (A1 region of 12-month-old animals. In NonTg mice, no specific labeling was observed (E), whereas neuronal CA1 labeling was evident within the cytoplasm and apical dendrites of $3 \times \mathrm{Tg}-\mathrm{AD}$ mice $(\boldsymbol{F})$. Significantly reduced labeling with TauCCP that was also limited primarily to the apical dendrites was observed in 3xTg-AD/BCl-2-0E animals $(\mathbf{G}, \boldsymbol{H})$. D , Confirmation by Western blot analysis that overexpression of $\mathrm{BCl}-2$ prevents the caspase cleavage of tau in 12-month-old 3xTg-AD/BCl-2-negative (littermates to BCl-2-OE mice) mice relative to NonTg animals. Western blot analysis was performed using a monoclonal antibody to caspase-cleaved tau (Gamblin et al., 2003) (Tau C3, 1:500). Tau C3 recognized a band ( $\sim 50 \mathrm{kDa}$ ) corresponding to caspase-cleaved tau in $3 \times \mathrm{xT}$-AD mice, which was largely prevented after the overexpression of the human Bcl-2 protein. $D$, Top, Western blot with an actin antibody, which served as a loading control. $I-L$, Intense TauCCP (A1 labeling was seen in 18-month-old 3xTg-AD mice (I), which appeared to be confined within cytoplasmic inclusion bodies (arrows; $J$ ). A paucity of staining with TauCCP was observed in two different 18-month-old 3xTg-AD mice that overexpressed BCl-2 $(K, L)$. Representative staining is shown from a total of $n=$ 4 animals for each cohort. Scale bars, $10 \mu \mathrm{m}$. M, Immunohistochemical quantification of labeled TauCCP neurons in the CA1 region of the hippocampus indicated an age-dependent increase in the number of positive neurons $(n=3 ; \pm S D)$.

level of $\mathrm{A} \beta_{1-42}$. We tested this hypothesis using an $\mathrm{A} \beta_{1-42^{-}}$ specific antibody. As shown in Figure $5 L$, lower levels of intracellular $\mathrm{A} \beta_{1-42}$ were detected in $3 \mathrm{xTg}-\mathrm{AD}$ mice overexpressing Bcl-2 relative compared with $3 \mathrm{xTg}-\mathrm{AD}$ mice (Fig. $5 \mathrm{~K}$ ). We also confirmed a reduction in insoluble $\mathrm{A} \beta_{1-42}$ and $\mathrm{A} \beta_{1-40}$ by ELISA in formic acid extracted cortical samples from 18-month-old animals. Insoluble $\mathrm{A} \beta_{1-42}$ and $\mathrm{A} \beta_{1-40}$ were reduced in $3 \times \mathrm{Tg}-\mathrm{AD} /$ Bcl-2-OE mice (44.45 pM/mg A $\beta_{1-42} ; 5.17 \mathrm{pm} / \mathrm{mg} \mathrm{A} \beta_{1-40}$ ) relative to $3 \times$ Tg-AD mice $\left(262.65 \mathrm{pm} / \mathrm{mg} \mathrm{A} \beta_{1-42} ; 11.04 \mathrm{pm} / \mathrm{mg} \mathrm{A} \beta_{1-}\right.$ 40) animals. Overall, these results suggest a significant role for caspase-like proteolytic activity in the processing of APP and production of $A \beta$. Further, despite the fact the protein levels of APP were significantly higher in $3 \mathrm{xTg}-\mathrm{AD} / \mathrm{Bcl}-2-\mathrm{OE}$ mice versus $3 \mathrm{xTg}-\mathrm{AD}$ mice, there was no evidence for extracellular plaques in these mice.

\section{Improved cognition in 3xTg-AD/Bcl-2-OE mice despite a lack of neurodegeneration}

Experiments were extended to include 24-month-old mice overexpressing $\mathrm{Bcl}-2$ and compared with $3 \mathrm{xTg}-\mathrm{AD}$ littermates that were $\mathrm{Bcl}-2$ negative. Confirmation of $\mathrm{Bcl}-2$ expression was confirmed using a human-specific antibody to Bcl-2 (Fig. 6A), whereas no labeling of Bcl-2 was seen in an age-matched $3 \times$ Tg-AD littermate (Fig. $6 B$ ). Detection of extracellular deposits of $\mathrm{A} \beta$ was evident in the 24 -month-old $3 \mathrm{xTg}$ - $\mathrm{AD}$ mouse that was negative for human $\mathrm{Bcl}-2$ protein (Fig. $6 D, F$, arrows). However, there was no evidence of extracellular deposits of $A \beta$ in a 24month-old 3xTg-AD/Bcl-2-OE mouse, although intracellular $\mathrm{A} \beta$ remained unaffected or was slightly elevated (Fig. $6 C, E$ ). These same two mice were behaviorally assessed before being killed, and there was a clear improvement place recognition memory of the 3xTg-AD mice overexpressing Bcl-2 versus chance (Fig. 6G). Statistical analyses were performed by single-sample $t$ tests against chance values ( 0.5 or $50 \%$, indicated by line). The average time spent exploring the novel location over the entire 3 min testing period for the $3 \times \mathrm{Tg}-\mathrm{AD} / \mathrm{Bcl}-2$-positive mouse was $0.77 \pm 0.12$ SEM versus $0.29 \pm 0.04$ SEM for the $3 x T g-A D / B c l-2$-negative mouse. Based on these results, the average time spent exploring the novel location was significantly greater than chance only in the Bcl-2-overexpressing mouse $(p=0.016)$. Pooled behavioral data from three different 3xTg-AD/Bcl-2-positive and Bcl-2negative mice indicated a significant improvement in place recognition memory in 3xTg-AD/Bcl-2-positive mice compared with 3xTg-AD littermates that were $\mathrm{Bcl}-2$ negative (Fig. $6 \mathrm{H}$ ).

Given the intact memory in $3 \times \mathrm{Tg}-\mathrm{AD} / \mathrm{Bcl}-2-\mathrm{OE}$ mice, we hypothesized that there would be less neurodegeneration, so we assessed neurodegeneration in 24-month-old mice by using FluoroJade $\mathrm{C}$ staining. FluoroJade $\mathrm{C}$ is a fluorescent dye that detects neuronal degeneration in a number of different animal models and displays a high degree of sensitivity and specificity (Bian et al., 2007; Slikker et al., 2007). In addition, FluoroJade C has been found to stain all degenerating neurons regardless of the specific 

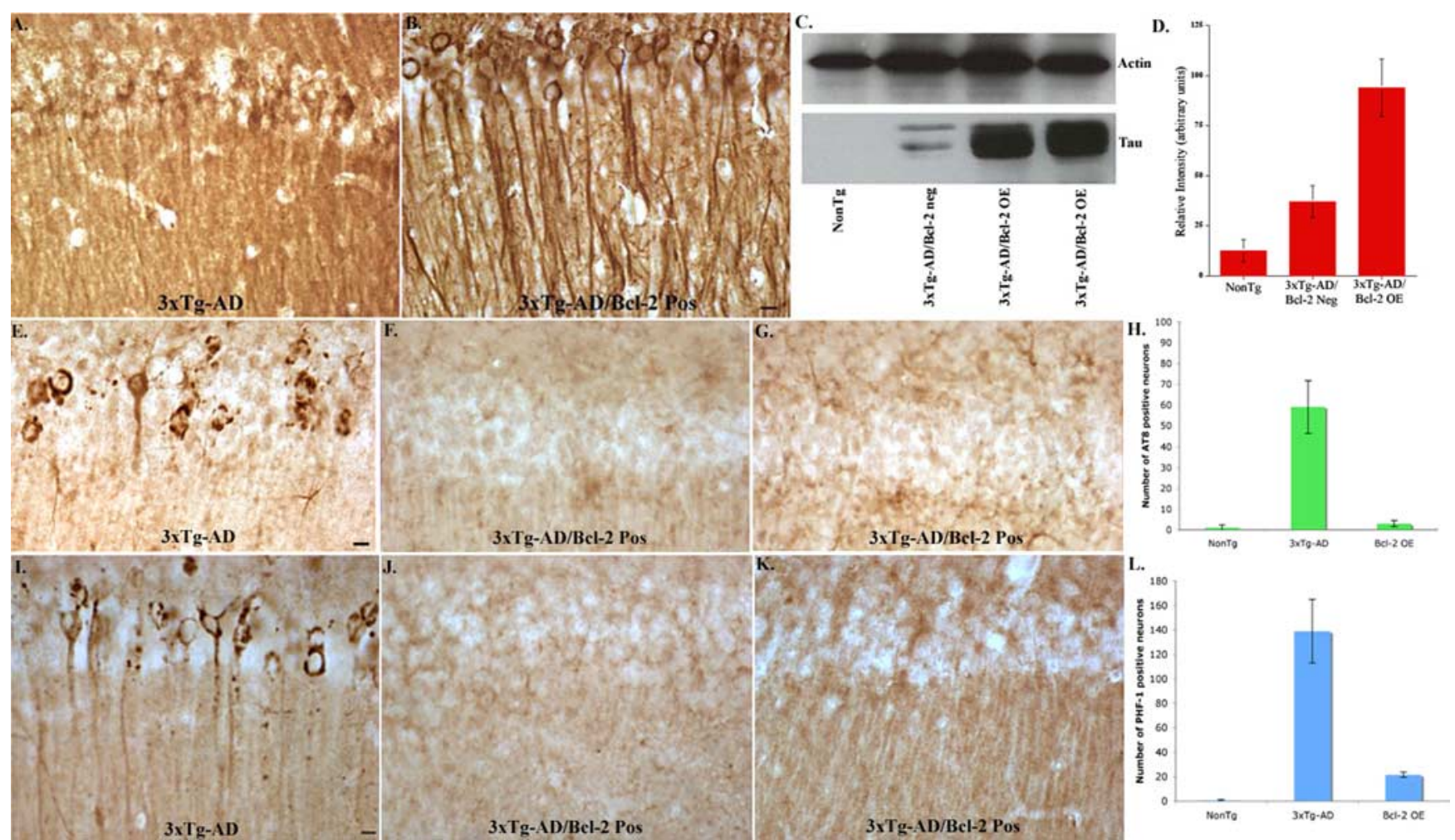

Figure 4. Overexpression of $B C-2$ in $3 \times T g-A D$ mice leads to an accumulation of human pathological tau and reduction in the number of tangles. $A, B$, Representative staining within the hippocampus is shown after application with anti-tau (HT7; 1:400). 3xTg-AD mice overexpressing BCl-2 (B) showed an enhanced intraneuronal labeling of human tau compared with 3xTg-AD mice alone $(\boldsymbol{A})$. C, Western blot analysis of total mouse brain lysates from 12-month-old animals showed increased levels of human tau in 3xTg-AD/BCl-2-0E mice compared with 3xTg-AD/BCl-2-negative littermates. C, Top, Western blot with an actin antibody, which served as a loading control. $D$, Densitometry analysis from three independent experiments ( \pm SD) to quantify the enhanced levels of human tau in 3xTg-AD/BCl-2-0E mice. A2.5-fold increase in the levels of human tau was evident in 3xTg-AD mice overexpressing BCl-2. E-G, Representative immunohistochemical staining with AT8 indicated a lack of positive neurons in $3 \times \mathrm{XTg}-\mathrm{AD} / \mathrm{BCl}-2-0 \mathrm{E}$ mice $(\boldsymbol{F}, \boldsymbol{G})$. $\boldsymbol{H}$, Immunohistochemical quantification for AT8 $(n=2 ; \pm \mathrm{SD})$. I-L, Similar results were obtained after application of a PHF-1 antibody. Representative staining is shown from a total of $n=4$ animals for each cohort. Scale bars, $10 \mu \mathrm{m}$.

insult or mechanism of cell death (necrosis and apoptosis) (Schmued et al., 2005). To confirm the utility of FluoroJade C as a specific marker for neurodegeneration, immunofluorescence experiments were undertaken using tissue sections from mice subjected to MCAO as described previously (Hou et al., 2006). This animal model of ischemia has the advantage that the ischemic infarct is confined to one side of the brain, leaving the other side intact and damage free. Application of FluoroJade C to MCAO brain sections revealed widespread neuronal labeling on the side of the brain subjected to ischemia (supplemental Fig. 1, available at www.jneurosci.org as supplemental material), whereas there was no labeling on the contralateral side of the brain (supplemental Fig. 1, available at www.jneurosci.org as supplemental material). These data indicate that FluoroJade C can be used as a specific marker for neurodegeneration in mouse brain. Experiments were then performed on 24-month-old $3 \times \mathrm{Tg}-\mathrm{AD} / \mathrm{Bcl}-2$-positive and -negative mice. In general, there was a complete lack of specific labeling with FluoroJade $\mathrm{C}$ in any of the animal groups examined, including age-matched NonTg controls (data not shown), 3xTg-AD/Bcl-2-negative, and 3xTg$\mathrm{AD} / \mathrm{Bcl}$-2-positive mice (supplemental Fig. 1, available at www.jneurosci.org as supplemental material). In addition to a lack of staining in the cortex, there was no labeling of FluoroJade $\mathrm{C}$ in the hippocampus of any of the mice examined (data not shown). These experiments were repeated in 18-month-old animals with similar results. Our findings using FluoroJade C support recent stereological analyses in areas CA1 and CA3 of the hippocampus and entorhinal cortex (both total and layer II, III, and V specific) indicating no significant loss of neurons or volume between 3xTg-AD mice and NonTg mice at 3 or 20 months of age (F. M. LaFerla, personal communication). Thus, the findings suggesting an improvement in cognition after overexpression of Bcl-2 cannot be explained by the ability of $\mathrm{Bcl}-2$ to afford protection from neurodegeneration.

\section{Discussion}

In $\mathrm{AD}, \mathrm{A} \beta$ deposition is accompanied by the gradual replacement of the neuronal cytoskeleton with insoluble NFTs. NFTs are intracellular fibrillary structures composed of aggregations of paired helical filaments (PHFs), which are made up of abnormally phosphorylated and truncated tau (Chun and Johnson, 2007). Although the diagnosis of $A D$ is dependent on the extent of accumulation of senile plaques and NFTs (Mirra et al., 1991), the exact relationship between these two neuropathological markers remains unknown. According to the $\mathrm{A} \beta$ hypothesis, $\mathrm{A} \beta$ deposition precedes NFT formation, suggesting that $A \beta$ may be the earliest event that triggers all subsequent downstream molecular events leading to neuronal death and synaptic loss (Golde et al., 2006). Several studies have now suggested that the putative link between $\mathrm{A} \beta$ and NFTs may be the activation of caspases and cleavage of tau, a microtubule-associated protein (Rohn et al., 2002; Gamblin et al., 2003; Rissman et al., 2004). In AD, tau undergoes aberrant phosphorylation and cleavage by caspases, modifications that are thought to contribute to the dysfunction and degeneration of neurons (Chun and Johnson, 2007). However, to date, direct evidence demonstrating that caspase cleavage 

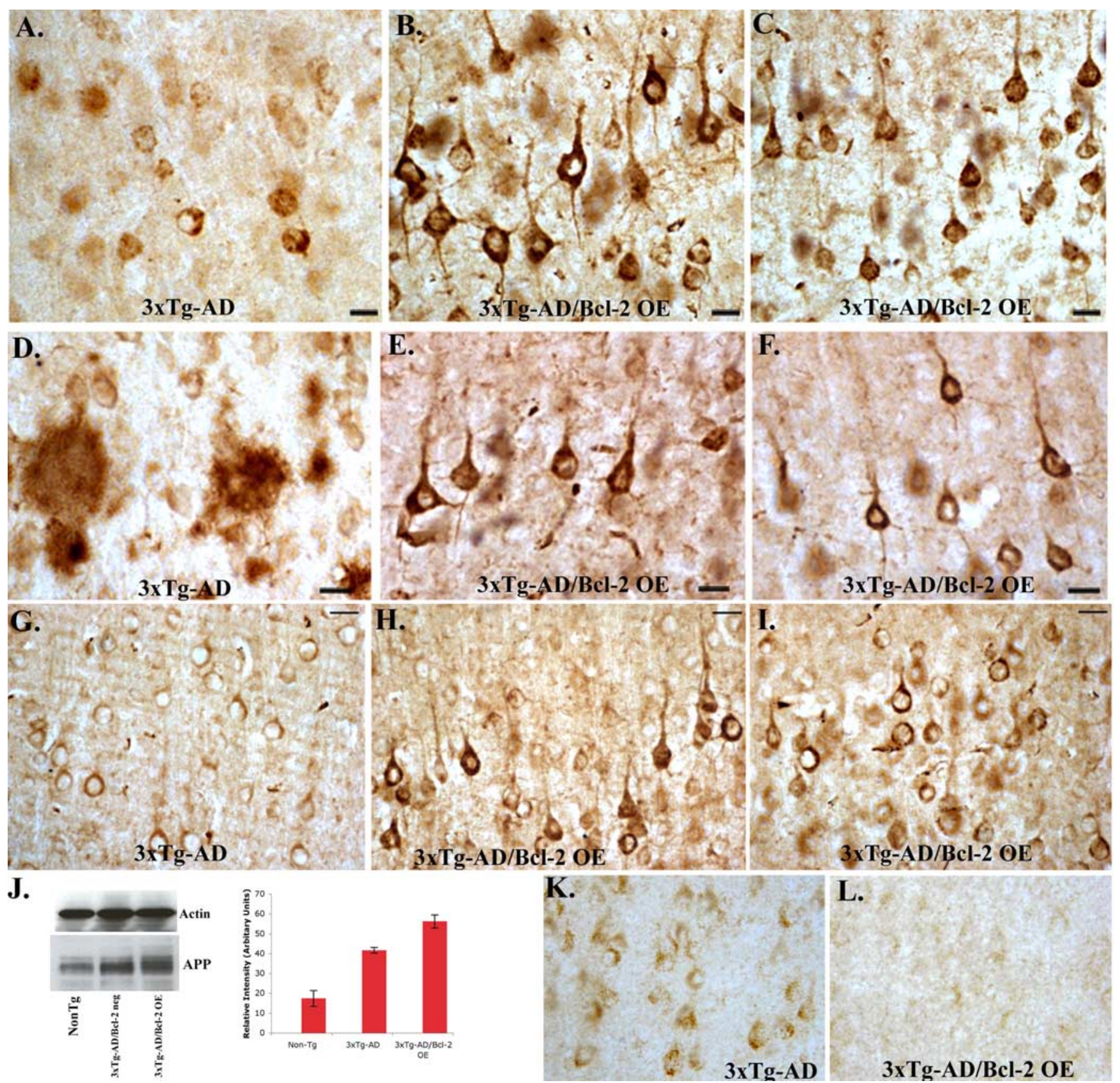

Figure 5. Overexpression of $B C l-2$ leads to an accumulation of APP in $3 \times T$ Tg-AD mice. $A-C$, Immunohistochemical analysis in a representative 12 -month-old $3 \times T g-A D$ mouse $(A)$ or in two different 3xTg-AD mice overexpressing BCl-2 (B, C) using monoclonal antibody 1560 (clone 6E10). The 3xTg-AD mouse showed immunolabeling for APP limited to the cytoplasm of cortical neurons (A). In contrast, intense staining was observed in the neocortex in animals overexpressing BCl-2, with an apparent accumulation of APP within the cytoplasm and apical dendrites (B, C). D-F, We extended these results to older, 18 -month-old animals. In older animals, extracellular deposits of $A \beta$ could be observed in $3 \times \mathrm{Tg}$-AD mice along with a concomitant decrease in intracellular immunoreactivity (D). In mice overexpressing BCl-2, immunoreactivity to antibody 1560 was confined within cortical neurons $(\boldsymbol{E}, \boldsymbol{F})$, and no extracellular deposits were observed. To determine whether intracellular labeling represented primarily APP or A $\beta$, we used the anti-APP specific antibody 22C11. In 3xTg-AD mice overexpressing BCl-2, there was stronger immunoreactivity to $22 \mathrm{C} 11$ in the neocortex $(\boldsymbol{H}$, I) compared with 3xTg-AD mice alone (G).J, Western blot and semiquantitative analysis of 12-month-old animals using the anti-APP antibody, 22C11 (1:1000) confirmed the higher levels of APP in $3 \times T g-A D / B C l-2-0 E$ mice compared with NonTg controls or $3 x T g-A D / B C l-2-$-negative mice. $K, L$, We next used an antibody specific for $A \beta_{1-42}$ and found that intracellular $A \beta$ immunoreactivity is much higher in neurons within the neocortex of a representative 12-month-old 3xTg-AD mouse $(\boldsymbol{K})$ then was found in $3 \times \mathrm{Tg}-\mathrm{AD} / \mathrm{BCl}-2-0 \mathrm{E}$ mice $(\boldsymbol{L})$. Representative staining is shown from a total of $n=4$ animals for each cohort. Scale bars, $10 \mu \mathrm{m}$.

of tau as an interlinking step between $\mathrm{A} \beta$ and NFTs in $\mathrm{AD}$ is lacking. The goal of the present study was to examine whether inhibition of caspases after overexpression of Bcl-2 prevents tangle alterations in a triple transgenic mouse model of AD.

Overexpression of Bcl-2 prevented the activation of caspase- 9 and caspase- 3 and limited the degree of caspase cleavage of tau in 6-, 12-, and 18-month-old 3xTg-AD mice. These data suggest that the caspase cleavage of tau may be a critical event in the evolution of tangle pathology. An additional finding of the present study was the accumulation of both human tau and APP. Thus, our results implicated caspase-like activity in the processing of APP and tau. The processing of APP into A $\beta$ represents one of the earliest known steps in the disease process, and much focus in this regard has been centered on the secretases $(\alpha, \beta$, and $\gamma)$ 

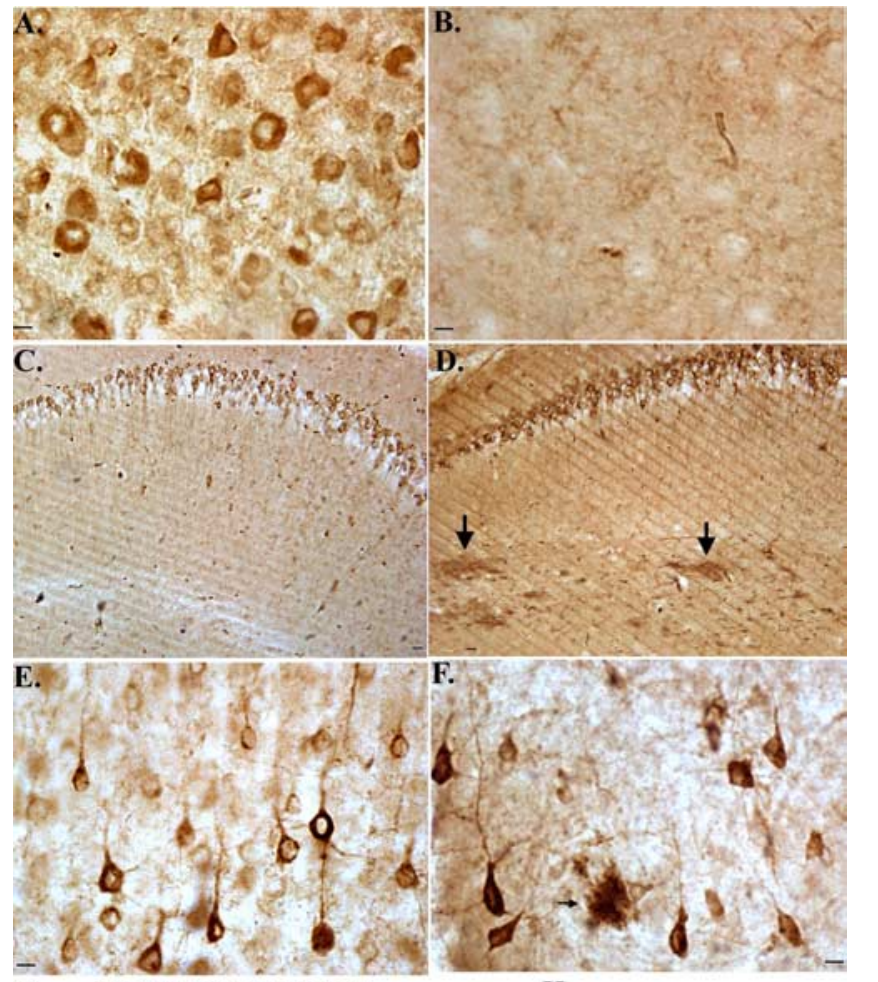

G. Place Recognition Memory

H.

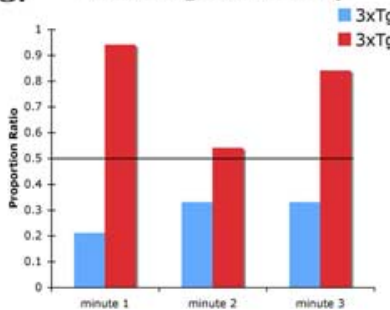

$3 \times T g-A D / B C l-2$ neg

H. $\left.\begin{array}{r}1 \\ 1 \\ 0.9\end{array}\right]$

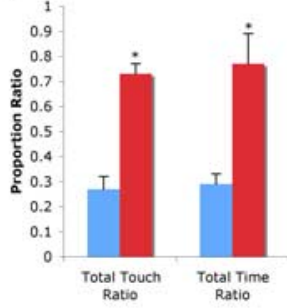

Figure 6. Assessment of memory retention in 3xTg-AD mice overexpressing $B C l-2 . A, C, E$, Representative staining from a 24 -month-old $3 x T g-A D / B C l-2-0$ E mouse. $\boldsymbol{B}, \boldsymbol{D}, \boldsymbol{F}$, Representative staining from a 24-month-old 3xTg-AD/BCl-2-negative littermate mouse. $\boldsymbol{A}, \boldsymbol{B}$, Cortical sections stained for $B C l-2$ using a monoclonal antibody to human $B C l-2$ (1:200). $\boldsymbol{C}-\boldsymbol{F}$, The mAb 1560 anti-A $\beta$ antibody (1:400) was incubated with tissue sections and immunolabeled extracellular $A \beta$ deposits in $3 x T g-A D / B C l-2$-negative mice ( $\boldsymbol{D}, \boldsymbol{F}$, arrows) that were absent in $3 x T g-A D / B C l-$ 2-0E mice $(\boldsymbol{C}, \boldsymbol{E})$. Scale bars: $\boldsymbol{A}, \boldsymbol{B}, \boldsymbol{E}, \boldsymbol{F}, 10 \mu \mathrm{m} ; \boldsymbol{C}, \boldsymbol{D}, 20 \mu \mathrm{m}$. $\boldsymbol{G}$, The same two mice used for pathological analysis were tested for place recognition memory retention before being killed. The $3 x \mathrm{Tg}-\mathrm{AD}$ mouse overexpressing human $\mathrm{BCl}-2$ showed superior place recognition, touching the object in the novel location more frequently on each of 3 testing minutes. $\boldsymbol{H}$, Pooled results ( $n=33 x T g-A D / B C l-2$ positive; $n=33 x T g-A D / B C l-2$ negative; \pm SEM) including data from the two animals in $\mathbf{G}$, indicating that $\mathrm{BCl}-2$ overexpressors explored the novel location significantly more than littermates that were $\mathrm{BCl}-2$ negative ( $p=0.008$ for total touch ratio and $p=0.02$ for total time ratio).

(Wilquet and De Strooper, 2004). Our data suggest that caspases may also contribute to the processing of APP, because overexpression of Bcl-2 led to an accumulation intracellular APP but a prevention of the extracellular deposition of $\mathrm{A} \beta$ in $3 \mathrm{xTg}-\mathrm{AD}$ mice. Together with the results concerning tau, these findings provide novel fundamental mechanisms governing the turnover of important neuronal proteins involved in the pathogenesis of $\mathrm{AD}$. Whether or not caspases play a physiological role in the normal turnover of tau and APP is a highly speculative but interesting question as more and more studies are identifying nonapoptotic functions for this class of enzymes (Yan et al., 2001; Rohn et al., 2004; Launay et al., 2005).

Although numerous studies have implicated caspases and ap- optosis as a major pathway of cell death in $\mathrm{AD}$ (Culmsee and Landshamer, 2006), our results suggest that the activation of apoptotic pathways may be an early event in $\mathrm{AD}$ and an important contributor to the disease process. Our findings support a recent study demonstrating the upregulation of Bcl-2 in APP transgenic mice, which was associated with neuroprotection (Karlnoski et al., 2007). Interesting, in this study the authors used APP + PS1 transgenic mice, in which previous studies have shown that $\mathrm{A} \beta$ induced neurodegeneration is limited (Karlnoski et al., 2007). In fact, the limited degree of neurodegeneration in this particular animal model may now be explained by an apparent increase in Bcl-2 expression in amyloid-containing brain regions (Karlnoski et al., 2007). Together with our study, these findings suggest that if one could selectively increase the levels or activity of Bcl-2 in neurons of AD patients, this could provide an effective means of treating this devastating disease. It seems unlikely, however, that one could develop pharmaceutical compounds that selectively activate Bcl-2 in neurons and not in other cell types such as glial cells, where overexpression could lead to tumor formation. Furthermore, Bcl-2 would be unable to distinguish "good" apoptosis versus "bad" apoptosis, and the possibility for numerous side effects would be a foreseeable outcome after the application of such an inhibitor of apoptosis.

A final outcome of the present study was the demonstration that overexpression of $\mathrm{Bcl}-2$ led to improved cognition in terms of memory retention in $3 \mathrm{xTg}-\mathrm{AD}$ mice. The improved cognition associated with overexpression of $\mathrm{Bcl}-2$ is intriguing and based on the FluoroJade $\mathrm{C}$ studies cannot be explained simply by preventing neurodegeneration. In fact, very little if any neurodegeneration was detected in 24-month-old 3xTg-AD mice in the presence or absence of Bcl-2. Our findings support recent stereological analyses in areas CA1 and CA3 of the hippocampus and entorhinal cortex, indicating no significant loss of neurons or volume between 3xTg-AD mice and NonTg mice at 3 or 20 months of age (LaFerla, personal communication). How then Bcl-2 is improving cognition in the present study is unknown, but may be related to actions of Bcl-2 independent of its classic role in apoptosis. For example, recent studies have suggested that Bcl-2 family members can influence synaptic activity, mitochondrial fission, and mitochondrial electrophysiology (Cheng et al., 2006). With regards to synaptic transmission, Jonas et al. (2003) showed that injection of the Bcl-2 family member, $\mathrm{Bcl}-\mathrm{xL}$, into nerve terminals enhanced postsynaptic responses by modulating mitochondrial membrane conductance. This action of Bcl-xL occurred independently of its well known role as anti-apoptotic molecule, suggesting that Bcl-2 family members may have other nonapoptotic functions in mature neurons. Previous studies have demonstrated age-related synaptic dysfunction in $3 \times \mathrm{Tg}-\mathrm{AD}$ mice, including long-term potentiation deficits (Oddo et al., 2003). Thus, the possibility exists that overexpression of Bcl-2 in $3 \mathrm{xTg}-\mathrm{AD}$ mice improves cognition through an action that is independent of its classic role as an anti-apoptotic protein by preserving or enhancing synaptic function. Future studies examining synaptic dysfunction in $3 x \mathrm{Tg}-\mathrm{AD}$ after overexpression of Bcl-2 should clarify this question. In conclusion, our results provide direct evidence that caspase activation may link $A \beta$ with NFTs and that caspases may play a role in the processing and turnover of both tau and APP. Thus, therapeutics designed to stimulate the activity of $\mathrm{Bcl}-2$ within neurons of the $\mathrm{AD}$ brain may provide an effective means for stopping the progression of this disease. 


\section{References}

Bian GL, Wei LC, Shi M, Wang YQ, Cao R, Chen LW (2007) Fluoro-Jade C can specifically stain the degenerative neurons in the substantia nigra of the 1-methyl-4-phenyl-1,2,3,6-tetrahydro pyridine-treated C57BL/6 mice. Brain Res 1150:55-61.

Bredesen DE, Rao RV, Mehlen P (2006) Cell death in the nervous system. Nature 443:796-802.

Cheng WC, Berman SB, Ivanovska I, Jonas EA, Lee SJ, Chen Y, Kaczmarek LK, Pineda F, Hardwick JM (2006) Mitochondrial factors with dual roles in death and survival. Oncogene 25:4697-4705.

Chun W, Johnson GV (2007) The role of tau phosphorylation and cleavage in neuronal cell death. Front Biosci 12:733-756.

Culmsee C, Landshamer S (2006) Molecular insights into mechanisms of the cell death program: role in the progression of neurodegenerative disorders. Curr Alzheimer Res 3:269-283.

Galvan V, Gorostiza OF, Banwait S, Ataie M, Logvinova AV, Sitaraman S, Carlson E, Sagi SA, Chevallier N, Jin K, Greenberg DA, Bredesen DE (2006) Reversal of Alzheimer's-like pathology and behavior in human APP transgenic mice by mutation of Asp664. Proc Natl Acad Sci USA 103:7130-7135.

Gamblin TC, Chen F, Zambrano A, Abraha A, Lagalwar S, Guillozet AL, Lu M, Fu Y, Garcia-Sierra F, LaPointe N, Miller R, Berry RW, Binder LI, Cryns VL (2003) Caspase cleavage of tau: linking amyloid and neurofibrillary tangles in Alzheimer's disease. Proc Natl Acad Sci USA 100:10032-10037.

Gervais FG, Xu D, Robertson GS, Vaillancourt JP, Zhu Y, Huang J, LeBlanc A, Smith D, Rigby M, Shearman MS, Clarke EE, Zheng H, Van Der Ploeg LH, Ruffolo SC, Thornberry NA, Xanthoudakis S, Zamboni RJ, Roy S, Nicholson DW (1999) Involvement of caspases in proteolytic cleavage of Alzheimer's amyloid-beta precursor protein and amyloidogenic A beta peptide formation. Cell 97:395-406.

Golde TE, Dickson D, Hutton M (2006) Filling the gaps in the abeta cascade hypothesis of Alzheimer's disease. Curr Alzheimer Res 3:421-430.

Hardy J, Selkoe DJ (2002) The amyloid hypothesis of Alzheimer's disease: progress and problems on the road to therapeutics. Science 297:353-356.

Hou ST, Jiang SX, Desbois A, Huang D, Kelly J, Tessier L, Karchewski L, Kappler J (2006) Calpain-cleaved collapsin response mediator protein-3 induces neuronal death after glutamate toxicity and cerebral ischemia. J Neurosci 26:2241-2249.

Jonas EA, Hoit D, Hickman JA, Brandt TA, Polster BM, Fannjiang Y, McCarthy E, Montanez MK, Hardwick JM, Kaczmarek LK (2003) Modulation of synaptic transmission by the BCL-2 family protein BCL-xL. J Neurosci 23:8423-8431.

Karlnoski R, Wilcock D, Dickey C, Ronan V, Gordon MN, Zhang W, Morgan D, Taglialatela G (2007) Up-regulation of Bcl-2 in APP transgenic mice is associated with neuroprotection. Neurobiol Dis 25:179-188.

Kostic V, Jackson-Lewis V, de Bilbao F, Dubois-Dauphin M, Przedborski S (1997) Bcl-2: prolonging life in a transgenic mouse model of familial amyotrophic lateral sclerosis. Science 277:559-562.

LaFerla FM, Tinkle BT, Bieberich CJ, Haudenschild CC, Jay G (1995) The Alzheimer's A beta peptide induces neurodegeneration and apoptotic cell death in transgenic mice. Nat Genet 9:21-30.

Launay S, Hermine O, Fontenay M, Kroemer G, Solary E, Garrido C (2005) Vital functions for lethal caspases. Oncogene 24:5137-5148.

LeBlanc AC (2003) Natural cellular inhibitors of caspases. Prog Neuropsychopharmacol Biol Psychiatry 27:215-229.

LeBlanc AC (2005) The role of apoptotic pathways in Alzheimer's disease neurodegeneration and cell death. Curr Alzheimer Res 2:389-402.

Letai A (2005) BCL-2: found bound and drugged! Trends Mol Med 11:442-444.

Lu DC, Rabizadeh S, Chandra S, Shayya RF, Ellerby LM, Ye X, Salvesen GS, Koo EH, Bredesen DE (2000) A second cytotoxic proteolytic peptide derived from amyloid beta-protein precursor. Nat Med 6:397-404.

Martinou J-C, Dubois-Dauphin M, Staple JK, Rodriguez I, Frankowski H, Missotten M, Albertini P, Talabot D, Catsicas S, Pietra C, Huarte J (1994) Overexpression of bcl-2 in transgenic mice protects neurons from natu- rally occurring cell death and experimental ischemia. Neuron 13:1017-1030.

Mercken M, Vandermeeren M, Lubke U, Six J, Boons J, Vanmechelen E, Van de Voorde A, Gheuens J (1992) Affinity purification of human tau proteins and the construction of a sensitive sandwich enzyme-linked immunosorbent assay for human tau detection. J Neurochem 58:548-553.

Mirra SS, Heyman A, McKeel D, Sumi SM, Crain BJ, Brounlee LM, Vogel FS, Hughes JP, VanBelle G, Berg L (1991) The consortium to establish a registry for Alzheimer's disease (CERAD) part II. Standardization of the neuropathological assessment of Alzheimer's disease. Neurol 41:479-486.

Mouser PE, Head E, Ha KH, Rohn TT (2006) Caspase-mediated cleavage of glial fibrillary acidic protein within degenerating astrocytes of the Alzheimer's disease brain. Am J Pathol 168:936-946.

Mumby DG, Gaskin S, Glenn MJ, Schramek TE, Lehmann H (2002) Hippocampal damage and exploratory preferences in rats: memory for objects, places, and contexts. Learn Mem 9:49-57.

Oddo S, Caccamo A, Shepherd JD, Murphy MP, Golde TE, Kayed R, Metherate R, Mattson MP, Akbari Y, LaFerla FM (2003) Triple-transgenic model of Alzheimer's disease with plaques and tangles: intracellular Abeta and synaptic dysfunction. Neuron 39:409-421.

Oddo S, Caccamo A, Smith IF, Green KN, LaFerla FM (2006) A dynamic relationship between intracellular and extracellular pools of Abeta. Am J Pathol 168:184-194.

Oppenheim RW (1991) Cell death during development of the nervous system. Annu Rev Neurosci 14:453-501.

Riedl SJ, Shi Y (2004) Molecular mechanisms of caspase regulation during apoptosis. Nat Rev Mol Cell Biol 5:897-907.

Rissman RA, Poon WW, Blurton-Jones M, Oddo S, Torp R, Vitek MP, LaFerla FM, Rohn TT, Cotman CW (2004) Caspase-cleavage of tau is an early event in Alzheimer disease tangle pathology. J Clin Invest 114:121-130.

Ritter PM, Marti A, Blanc C, Baltzer A, Krajewski S, Reed JC, Jaggi R (2000) Nuclear localization of procaspase- 9 and processing by a caspase-3-like activity in mammary epithelial cells. Eur J Cell Biol 79:358-364.

Rohn TT, Rissman RA, Davis MC, Kim YE, Cotman C, Head E (2002) Caspase-9 Activation and caspase cleavage of tau in the Alzheimer's disease brain. Neurobiol Dis 11:341-354.

Rohn TT, Cusack SM, Kessinger SR, Oxford JT (2004) Caspase activation independent of cell death is required for proper cell dispersal and correct morphology in PC12 cells. Exp Cell Res 295:215-225.

Schmued LC, Stowers CC, Scallet AC, Xu L (2005) Fluoro-Jade C results in ultra high resolution and contrast labeling of degenerating neurons. Brain Res 1035:24-31.

Shimohama S, Tanino H, Fujimoto S (2001) Differential subcellular localization of caspase family proteins in the adult rat brain. Neurosci Lett 315:125-128.

Slikker Jr W, Zou X, Hotchkiss CE, Divine RL, Sadovova N, Twaddle NC, Doerge DR, Scallet AC, Patterson TA, Hanig JP, Paule MG, Wang C (2007) Ketamine-induced neuronal cell death in the perinatal rhesus monkey. Toxicol Sci 98:145-158.

Su JH, Satou T, Anderson AJ, Cotman CW (1996) Up-regulation of BCL-2 is associated with neuronal DNA damage in Alzheimer's disease. NeuroReport 7:437-440.

Sugarman MC, Yamasaki TR, Oddo S, Echegoyen JC, Murphy MP, Golde TE, Jannatipour M, Leissring MA, LaFerla FM (2002) Inclusion body myositis-like phenotype induced by transgenic overexpression of beta APP in skeletal muscle. Proc Natl Acad Sci USA 99:6334-6339.

Vaux DL, Korsmeyer SJ (1999) Cell death in development. Cell 96:245-254.

Wilquet V, De Strooper B (2004) Amyloid-beta precursor protein processing in neurodegeneration. Curr Opin Neurobiol 14:582-588.

Yan XX, Najbauer J, Woo CC, Dashtipour K, Ribak CE, Leon M (2001) Expression of active caspase-3 in mitotic and postmitotic cells of the rat forebrain. J Comp Neurol 433:4-22.

Zhao M, Su J, Head E, Cotman CW (2003) Accumulation of caspase cleaved amyloid precursor protein represents an early neurodegenerative event in aging and in Alzheimer's disease. Neurobiol Dis 14:391-403. 